\title{
TABANIDAE (DIPTERA) OF AMAZONIA. IV. DESCRIPTION \\ OF FIDENA BISTRIGA, SP. N. AND \\ CATACHLOROPS OVERALI, SP. N.
}

G. B. FAIRCHILD I

J. A. RAFAEL 23

\section{ABSTRACT}

Two new species of Tabanidae are described from the Amazon Basin: Fidena bistriga and Catachlorops overali.

Fidena bistriga, sp. n.

A slender blackish species with a pair of broad pale stripes on mesonotum, pale pilose bands on abdominal tergites 2 and 5 , pale triangles on tergites 3 and 4, white beard and venter, unicolorous legs and yellowish tinted wings with first posterior cell closed and petiolate.

Female. Length $13 \mathrm{~mm}$, of wing $12 \mathrm{~mm}$. Eyes pilose, the pilosity moderately sparse but long, the eye color not recorded. Head structures as figured (Plate 1). Integument of frons black, rather thinly dark brown pollinose. Ocellar tubercle pollinose, prominent, with 3 conspicuous ocelli. Vertex with long erect black hairs and a post-ocular fringe of short well spaced black bristles. Occiput with a few iong lax pale hairs. Subcallus paler brown in middle, pale gray at sides. Fronto-clypeus with light brown integument, bare and shiny dorsally and along lower margin, gray pollinose on upper sides and next the eyes. Beard long, derse, snow white; antennae orange brown, the scape and pedicel grayish pollinose, beset with short sparse black bristles, the style of 8 segments, the first the widest and over twice length of second, the terminal segment dusky, about twice length of penultimate segment. Palpi dark brown, the basal segment cylindrical, about as long as terminal segment, the latter reddish brown, the apex drawn out into a slender point, with short bristles only along the margin. Theca and labella of proboscis black, minutely annulate, the stylets about length of fore tibiae and tarsi.

Mesonotum with integument blackish brown, the scutellum paler. Vestiture thinly brown pollinose with a pair of broad gray pollinose stripes from fore border nearly to scutellum, broadest at posterior end. Extreme sides of mesonotum, including notopleural lobes, pale gray pollinose. Pilosity is dark, sparse and erect over the central mesonotum, becoming white, dense and recumbent along sides to, but not onto, scutellum. Scutellum yellowish in ground color, dark pollinose basally becoming white or pale gray apically, whith long sparse erect dark hairs. Pleura white pollinose and entirely creamy white pilose, except for a patch of erect black hairs in front of wing bases and extending forward to cover notopleural lobes. Coxae brown, white pollinose and white haired. Remainder of legs dark yellowish brown, sparsely black haired. Wings (Plate 2) with brown veins, the first posterior cell closed and petiolate. Membrane smoky yellowish brown, the costal cell yellow. Halteres light yellow.

Abdomen with dary brown integument, somewhat paler and yellowish on tergite 1 and base of 2, black haired dorsally except for narrow silvery white pilose bands on the hind margins of tergites 2 and 5 , and broad low white pilose triangles in the middle of the hind margins of tergites 3 and 4.

1. Departament of Entomology, University of Florida, Gainesville, Florida 32611, USA.

2. Instituto Nacional de Pesquisas da Amazônia, C.P. 478, 69000, Manaus, AM.

3. Endereço temporário: Universidade Federal do Paraná, C.P. 3034, Departamento de Zoologia, 80000, Curitiba, PR. 

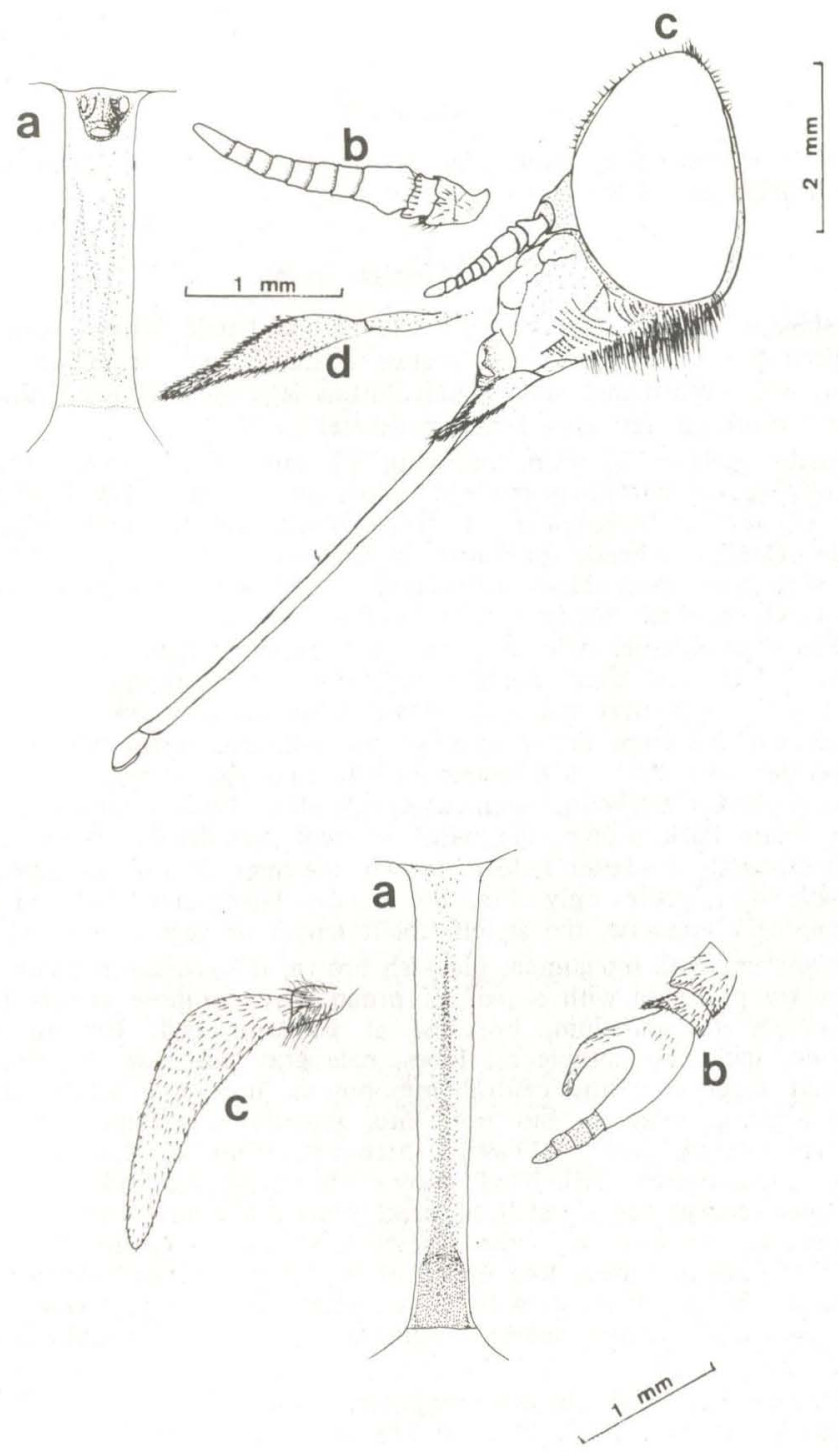

Plate 1 - Upper row: Fidena bistriga, sp. n. - a. frons; b. antenna; c. head, lateral view; d. palpus (Holotype + ). Lower row: Catachlorops overali, sp. n. — a. frons; b. antenna; c. palpus (Holotype + ). 

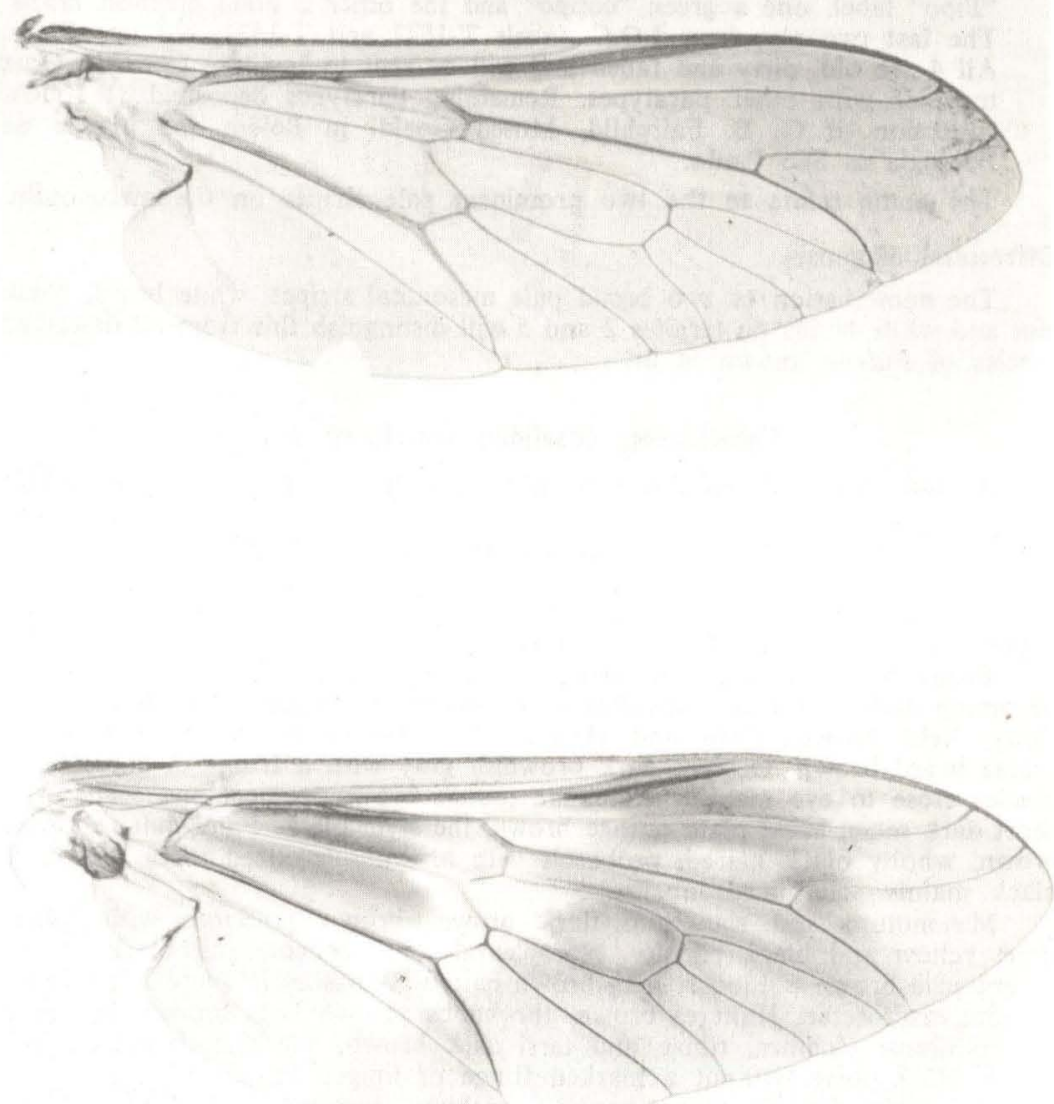

Plate 2 - Wings of Fidena bistriga, sp. n. (upper) and Catachlorops overali, sp. n. (lower) (Both Paratype o ). 
The extreme sides of first 2 tergites are largely white pilose and there are small tufts of white hairs at sides of tergites 5 and 6 . The venter is entirely white pollinose and white haired.

Male: unknown.

Distribution: Brazil (Pará, Mato Grosso and Rondônia).

Examined material: Holotype female: BRASIL, Rondônia: Vilhena, 06.xi.1979 (Jorge Arias), in the Systematic Entomology Collection of INPA, Manaus. Paratypes: $40 \%$, same data as holotype; 1 o, BRASIL, Pará: Transamazônica, Itaituba-Altamira, $\mathrm{km} \mathrm{25,} \mathrm{xi.1971} \mathrm{(ADLN);} 1$ 잉. Mato Grosso: Aripuanã, 08.x.1978 (T. F. Forest); 4 ㅇ ๆ, "Utiarity, 2.9.11, Capanema, 25.9.11" ex coll. Lutz. This we believe means that they were taken

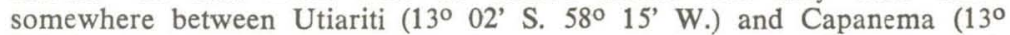
$17^{\prime}$ S. $57^{\circ} 5^{\prime}$ 'W.) in north-western Mato Grosso. One bears a pink "Tipo" label, one a green "cotipo" and the other 2 plain greenish labels. The last two also bear I.O.C. labels T-1522 and T-1523, but no names. All 4 are old, dirty and faded and will be sent to Instituto Oswaldo Cruz together with other paratypes. Remaining paratypes deposited at INPA, collection of G. B. Fairchild, Museu Goeldi in Belém and Museu de Zoologia in São Paulo.

The name refers to the two prominent pale stripes on the mesonotum.

Diferential diagnosis.

The combination of two broad pale mesonotal stripes, white beard, black legs and white bands on tergites 2 and 5 will distinguish this from all described species of Fidena known to us.

\section{Catachlorops (Psalidia) overali, sp. n.}

A dark brownish species with bare subcallus, largely infuscated wings with a narrow yellowish hyaline patch covering distal ends of basal cells and proximal ends of distal and contiguous cells. Wing apex indistinctly paler.

Female. Length $17 \mathrm{~mm}$, of wing $15 \mathrm{~mm}$. Eyes bare, without pattern, coppery bronze in life. Head structures as figured (Plate 1). Frontal index 9.5. Frons brownish gray pollinose, the callus shiny, reddish brown below, becoming dark at vertex. Subcallus more yellowish pollinose, largely bare and shiny, light brown. Face and cheecks dark yellowish gray pollinose, the sparse beard brown. Occiput dark brownish gray with a fringe of short black blistles close to eye margin. Antennae orange brown, pedicel and scape with short dark setae, basal plate orange brown, the style black. Palpi dull yellowish brown, wholly black haired, proboscis with brown sclerotized theca and large black mainly sclerotized labella.

Mesonotum and scutellum dark brown, brown pollinose with mixed short yellow and black pilosity. Notopleural lobes concolorous, black haired. Pleura pale brown pollinose, long brown haired. Wings as in Plate 2. Basicosta without macrosetae. Halteres brown, the knobs yellow. Legs brown, the coxae pale pollinose, femora, tibiae and tarsi dark brown, subshiny, entirely black pilose. Hind tibiae without a marked fringe of longer hairs.

Abdomen dorsally dark brown, subshiny, entirely clothed with black hairs. Beneath the abdomen is yellowish brown, pale pollinose, clothed with sparse dark and yellowish hairs, the latter forming indistinct hind marginal fringes on the sterna.

Male: unknown.

Distribuition: Brazil (Amazonas).

Examined material: Holotype female. BRASIL, Amazonas: Manaus, Reserva Ducke, 17.ix.1981 (J. A. Rafael). Deposited in the Systematic Entomology Collection of INPA, Manaus. 
Paratypes: All from BRASIL, Amazonas: vicinity of Manaus. 2 $\uparrow$, Embrapa. 12.xi.1976 (W. L. Overal); 1 ㅇ, Ceplac, AM 010 km 30, 19.vi.1976 (Mario Dantas); 11 우, same locality, 03.x., 31,vii and 17.vii.1975 (J. Arias); 2 ㅇ , same loc., 31.v.1979 (J. A. Rafael); 1 \&, Reserva Ducke, 18.vi.1976 (A. P. A. Luna Dias); 2 ᄋ \&, Campus Universitário, 09.ix.1978 (J. A. Rafael); 11 우, Reserva Ducke, 18.vii., 25.vii., 30.v., 01.viii., 29.viii., 20.vi and 13.ix.1978 (J. Arias and N. Penny); 5 우 오, same loc., 24.ix., 21.viii., 05.x. and 13.x.1981 (J. A. Rafael); 1 ᄋ, Ceplac, AM 010-km 30, 29.xi.1976 (W. L. Overal); 2 \% $\%$, Reserva Ducke 14 and 17.viii.1981 (G. B. Fairchild); 4 우, Reserva Ducke, 24.viii. and 24.ix.1982 (J. A. Rafael). To be deposited at INPA, G. B. Fairchild collection and Museu Goeldi, Belém.

The species is named for Dr. William L. Overal, of the Museu Goeldi, Belém, who aside from collecting some of the specimens, furnished the authors with invaluable support and encouragement.

\section{Diferential diagnosis}

This species is most similar to conspicuus Lutz \& Neiva from which it differs in the presence of an inflated and bare subcallus, strongly infuscated basal cells, less extensively hyaline wing apex and absence of any indication of hyaline fenestrae in the submarginal cells. From medemi Philip this new species differs in smaller size, darker color, more extensive dark wing markings and narrower frons. 